\title{
Clinicopathological characteristics of ROS1- and RET-rearranged NSCLC in caucasian patients: Data from a cohort of 713 non-squamous NSCLC lacking KRAS/EGFR/HER2/BRAF / PIK3CA/ ALK alterations
}

\author{
Frédéric Dugay ${ }^{1,2}$, Francisco Llamas-Gutierrez ${ }^{3}$, Marjory Gournay ${ }^{1}$, Sarah Medane ${ }^{1}$, \\ François Mazet $^{1}$, Dan Christian Chiforeanu ${ }^{3}$, Emmanuelle Becker ${ }^{2}$, Régine \\ Lamy ${ }^{4}$, Hervé Léna ${ }^{5}$, Nathalie Rioux-Leclercq ${ }^{2,3}$, Marc-Antoine Belaud-Rotureau ${ }^{1,2}$ \\ and Florian Cabillic ${ }^{1,6}$

\footnotetext{
${ }^{1}$ Department of Cytogenetics and Cell Biology, CHU de Rennes, Rennes, France

${ }^{2}$ IRSET UMR INSERM 1085, Faculté de Médecine, Université de Rennes 1, Rennes, France

${ }^{3}$ Department of Pathology, CHU de Rennes, Rennes, France

${ }^{4}$ Department of Pneumology, $\mathrm{CHU}$ de Lorient, Lorient, France

${ }^{5}$ Department of Pneumology, CHU de Rennes, Rennes, France

${ }^{6}$ INSERM, INRA, Université de Rennes 1, Université Bretagne Loire, Nutrition Metabolisms and Cancer, Rennes, France Correspondence to: Florian Cabillic, email: florian.cabillic@chu-rennes.fr

Keywords: non-small cell lung cancer, ROSI, RET, fusion genes, caucasian population

Received: December 12, $2016 \quad$ Accepted: May 13, $2017 \quad$ Published: June 08, 2017

Copyright: Dugay et al. This is an open-access article distributed under the terms of the Creative Commons Attribution License 3.0 (CC BY 3.0), which permits unrestricted use, distribution, and reproduction in any medium, provided the original author and source are credited.
}

\section{ABSTRACT}

Targeted therapies have substantially changed the management of non-small cell lung cancer (NSCLC) patients with driver oncogenes. Given the high frequency, EGFR and $A L K$ aberrations were the first to be detected and paved the way for tyrosine kinase inhibitor (TKI) treatments. Other kinases such as ROS1 and more recently RET have emerged as promising targets, and ROS1 and RET TKIs are already available for precision medicine.

We screened a large cohort of 713 Caucasian non-squamous NSCLC patients lacking EGFR/KRAS/BRAF/HER2/PI3KCA/ALK aberrations for ROS1 and RET rearrangements using fluorescence in situ hybridization to determine the frequency and clinicopathological characteristics of ROS1- and RET-positive patients.

Frequencies of ROS1 and RET rearrangements were $2.1 \%$ and $2.52 \%$, respectively. Contrary to common belief, both ROS1 and RET rearrangements were detected in patients with a history of smoking, and the RET-positive patients were not younger than the negative patients. Moreover, RET but not ROS1 rearrangement was associated with the female gender. Nearly half of the ROS1-rearranged patients were successfully treated with ROS1 TKIs. In contrast, only 5/18 RET-positive patients received off-label RET TKIs. Two patients had stable disease, and three experienced disease progression. In addition to the 18 RET-positive cases, 10 showed isolated 5' signals. The clinical relevance is unknown but if the frequency is confirmed by other groups, the question whether these patients are eligible to TKIs will arise. More potent RET TKIs are under development and may improve the response rate in RET-positive patients. Therefore, we recommend the routine implementation of RET testing in nonsquamous NSCLC patients, including those with a history of smoking. 


\section{INTRODUCTION}

Non-small cell lung cancer (NSCLC) is one of the leading causes of cancer-related death worldwide, accounting for approximately 1.8 million deaths every year [1]. During the past few years, several gene aberrations have been identified as oncogenic drivers in NSCLC, including epidermal growth factor receptor $(E G F R)$ and Kirsten rat sarcoma viral oncogene homolog (KRAS) [2]. In 2007, anaplastic lymphoma kinase $(A L K)$ was the first gene reported to cause lung adenocarcinoma upon a chromosomal rearrangement resulting in a fusion gene [3]. Very soon, impressive clinical responses with ALK tyrosine kinase inhibitor (TKI) crizotinib were reported [4] and prompted further investigation on the role of fusion genes in NSCLC. Those efforts led to the identification of new fusion genes involving ROS1 and rearranged during transfection $(R E T)[5,6]$. Both ROS1 and RET belong to the receptor tyrosine kinase superfamily. ROS1 belongs to the insulin subgroup and shares a high degree of homology within the kinase domain with ALK. Its precise role still remains to be established [7]. RET is phylogenetically related to the fibroblast growth factor receptors and is required for the development of the kidneys and nervous system as well as for the maturation and maintenance of hematopoietic stem cells [8]. The oncogenic role of ROS1 was described in 1987 [9], but the role of ROS1 fusion proteins in NSCLC was demonstrated later with the identification of SLC34A2ROS1 fusion in 2007 [5]. Likewise, aberration in RET has long been known to be involved in thyroid cancers, but the first RET fusion gene in NSCLC was found in early 2012 [6]. Since then, various ROS1 and RET fusion-partners have been reported in NSCLC, and all together these variants are thought to cause $2 \%$ to $4 \%$ of lung adenocarcinoma [10]. ROS1 - and RET-rearranged NSCLC patients share clinical characteristics with $A L K$-positive NSCLC patients, including young age of onset and minimal to no previous history of smoking [11, 12]. Interestingly, ROS1- and RET-targeted therapies are already available for precision medicine.

Here, we report the frequency of ROS1 and RET rearrangements in a large cohort of 713 Caucasian patients with non-squamous NSCLC lacking EGFR/KRAS/BRAF/ HER2/PI3KCA/ALK alterations by using fluorescence in situ hybridization (FISH). We investigate the correlation between fusion-positive tumors and clinicopathological features, and we report the clinical outcome of patients treated with crizotinib or investigational RET TKIs.

\section{RESULTS}

\section{Percentage of samples with $R E T$ rearrangement slightly exceeds that of ROS1}

ROS1 rearrangements were found in $15(2.1 \%)$ samples (Table 1). The hybridization profiles were as follows: isolated 3' signals $(\mathrm{n}=4)$, split signals $(\mathrm{n}=7)$ or a combination of both $(n=4)$ (Table 2, Figure 2B and 2D). ROS1 protein was detected in 13/15 ROS1-rearranged samples. In addition, RET rearrangements were found in $18(2.5 \%)$ samples: most of them $(\mathrm{n}=14)$ had split signals whereas 4 samples exhibited isolated 3' signals (Table 3, Figure $2 \mathrm{~F}$ and $2 \mathrm{H}$ ). Ten additional cases showed isolated 5 ' signals and were considered RET-negative (Figure 3D). The copy number of genes was also recorded in both rearranged and non-rearranged cases (Table 4). Of the samples, $7 \%$ had a single copy of ROS1, and one sample exhibited ROS1 amplification without protein overexpression (Figure 3A and 3B). Copy number gain $(\mathrm{CNG})$ was more frequently observed for RET compared to ROS1 (Table 4). No significant differences in $\mathrm{CNG}$ frequencies were noted between rearranged and nonrearranged samples.

\section{$R E T$ rearrangement is more frequent in women and can cause NSCLC in smokers}

ROS1 rearrangement was more frequent in younger patients $(\mathrm{p}=0.02)$ but was not found to be significantly associated with gender (Tables 1 and 2). Six patients were never smokers and 8 patients were former or current smokers (Tables 1 and 2). Most of the ROS1 rearrangements were detected in adenocarcinoma (14/15) but no enrichment in a particular histological subtype was demonstrated (Tables 1 and 2). ROS1 rearrangement was found in acinar $(n=5)$, solid $(n=4)$, lepidic $(n=3)$ and papillary $(n=1)$ adenocarcinoma (Tables 1 and 2, Figure $2 \mathrm{~A}$ and $2 \mathrm{C}$ ).

$R E T$ rearrangement was not significantly associated with age but was more frequently found in female patients $(\mathrm{p}=0.04)$ (Tables 1 and 3). Seven patients were never smokers and 10 patients were former or current smokers (Tables 1 and 3). Most of the RET-positive cases were detected in advanced stage tumors (13/18 stages III/IV). RET rearrangement was found in 17 adenocarcinoma and in one carcinoma not otherwise specified (NOS). Solid growth pattern tended to be more frequent (9/17), and signet-ring cells were reported in three samples (Tables 1 and 3 , Figure $2 \mathrm{E}$ and $2 \mathrm{G}$ ).

\section{Unlike ROS1, therapy for RET-positive patients still needs to be refined}

The treatments given and disease outcomes were collected. Among the ROS1-positive patients, 7/15 received ROS1-targeted therapy. Five patients achieved partial $(n=3)$ or complete $(n=2)$ responses. One patient had stable disease and one patient who developed metastases prior to starting crizotinib experienced progressive disease (Table 2). After initial crizotinib relapse, 3 patients were given second- or third-generation TKIs (ceritinib or lorlatinib). In addition, 4 patients underwent curative surgery, and 3 
Table 1: Clinicopathological characteristics of $R O S 1$ - and $R E T$-rearranged patients

\begin{tabular}{|c|c|c|c|c|c|c|}
\hline & \multicolumn{3}{|c|}{ ROS1 } & \multicolumn{3}{|c|}{ RET } \\
\hline & + & - & $\mathbf{p}$ & + & - & $\mathbf{p}$ \\
\hline \multicolumn{7}{|l|}{ Number $(n=713)$} \\
\hline & 15 & 698 & & 18 & 695 & \\
\hline \multicolumn{7}{|l|}{ Age (years) } \\
\hline Mean & 59.1 & 65.6 & 0.02 & 67.7 & 65.4 & 0.55 \\
\hline $\mathrm{SD}$ & 14 & 10.7 & & 15.4 & 10.7 & \\
\hline \multicolumn{7}{|l|}{ Sex } \\
\hline Male & 9 & 479 & 0.58 & 8 & 480 & 0.04 \\
\hline Female & 6 & 219 & & 10 & 215 & \\
\hline \multicolumn{7}{|l|}{ Smoking history $(\mathrm{n}=551)$} \\
\hline Never & 6 & 93 & 0.03 & 7 & 92 & 0.02 \\
\hline Current/former & 8 & 444 & & 10 & 442 & \\
\hline \multicolumn{7}{|l|}{ Stage at diagnosis $(n=574)$} \\
\hline $\mathrm{I} / \mathrm{II}$ & 2 & 126 & 0.64 & 5 & 123 & 0.09 \\
\hline III & 5 & 148 & & 1 & 152 & \\
\hline IV & 7 & 286 & & 12 & 281 & \\
\hline \multicolumn{7}{|l|}{ Tumor histology } \\
\hline Adenocarcinoma & 14 & 587 & 0.49 & 17 & 584 & 0.33 \\
\hline Other & 1 & 111 & & 1 & 111 & \\
\hline \multicolumn{7}{|l|}{ Adenocarcinoma subtype } \\
\hline Solid & 4 & 182 & 0.73 & 9 & 177 & 0.27 \\
\hline Acinar & 5 & 157 & & 4 & 158 & \\
\hline Lepidic & 3 & 85 & & 1 & 87 & \\
\hline Papillary & 1 & 111 & & 1 & 111 & \\
\hline Undetermined/cytology & 1 & 52 & & 2 & 51 & \\
\hline
\end{tabular}

patients were treated with chemotherapy alone. Among the RET-positive patients, only $5 / 18$ received the RET inhibitors vandetanib or sunitinib. Among them, 2 patients had stable disease and three experienced clinical deterioration with disease progression (Table 3). In addition, 4 patients benefited from curative surgery and 5 patients were treated with chemotherapy alone. Of note, one ROS1-positive and 4 RET-positive patients were given the anti-PD-1 immune checkpoint inhibitor nivolumab, but none experienced clinical response.

\section{DISCUSSION}

Most of the available data regarding gene rearrangement in NSCLC, especially RET fusion, come from Asian patients. Although to a lesser extent than in EGFR-driven tumors, ethnic heterogeneity have been reported in fusion gene-induced tumors [2, 13, 14]. Hence, our study provides specific information about the Caucasian population. Among 713 non-squamous NSCLC lacking EGFR/KRAS/HER2/BRAF/PI3KCA/ALK aberrations, we reported $2.1 \%$ and $2.5 \%$ ROS1 and RET rearrangements, respectively. As the cohort composition is highly variable across studies (NSCLC, non-squamous NSCLC, ADK or ADK lacking mutations), interstudy comparison requires prior adjustments. The levels found in this study were lower than those reported in the Asian population [15-17], but they were in line, once adjusted, with European studies [18-20]. Indeed, extrapolation to unselected NSCLC patients would give between $0.5 \%$ 
Table 2: Clinical, histological and molecular features of ROS1-rearranged patients

\begin{tabular}{|c|c|c|c|c|c|c|c|c|c|c|c|}
\hline No & $\begin{array}{l}\text { Sex/ } \\
\text { Age }\end{array}$ & $\begin{array}{c}\text { ROS1 } \\
\text { diagnosis } \\
\mathbf{m m} / \mathbf{y y}\end{array}$ & $\begin{array}{l}\text { Last news } \\
\text { or death } \\
(+) \mathbf{m m} / \mathbf{y y}\end{array}$ & $\begin{array}{c}\text { Smoker } \\
\text { (pack- } \\
\text { year) }\end{array}$ & TNM & Stage & $\begin{array}{l}\text { Histological } \\
\text { subtype/ } \\
\text { Predominant } \\
\text { pattern }\end{array}$ & $\begin{array}{l}\text { FISH- } \\
\text { positive } \\
\text { rate }(\%)\end{array}$ & $\begin{array}{c}\text { FISH } \\
\text { pattern }\end{array}$ & $\begin{array}{c}\text { Lines of } \\
\text { treatment } \\
\text { Date } \mathrm{mm} / \mathrm{yy} \text { (nb } \\
\text { of cycles)-Cause } \\
\text { of therapeutic } \\
\text { escape }\end{array}$ & $\begin{array}{c}\text { Best } \\
\text { response }\end{array}$ \\
\hline 1 & $\mathrm{M} / 49$ & $02 / 14$ & $01 / 16$ & $\begin{array}{l}\text { Current } \\
\text { (10) }\end{array}$ & $\mathrm{T} 1 \mathrm{bN} 2 \mathrm{M} 0$ & IIIa & $\begin{array}{l}\text { ADK/Acinar } \\
\text { signet-ring } \\
\text { cells }\end{array}$ & 90 & IGS & $\begin{array}{c}\text { 1. Surgery } \\
+ \text { adjuvant } \\
\text { cisplatin/ } \\
\text { vinorelbine }\end{array}$ & $\begin{array}{l}\text { Complete } \\
\text { response }\end{array}$ \\
\hline \multirow[t]{4}{*}{2} & \multirow[t]{4}{*}{$\mathrm{F} / 51$} & \multirow[t]{4}{*}{$04 / 14$} & \multirow[t]{4}{*}{$11 / 15(+)$} & \multirow[t]{4}{*}{$\begin{array}{l}\text { Former } \\
\text { (10) }\end{array}$} & \multirow[t]{4}{*}{ T3N2M1b } & \multirow[t]{4}{*}{ IV } & \multirow[t]{4}{*}{ ADK/Acinar } & \multirow[t]{4}{*}{90} & \multirow[t]{4}{*}{ Split } & $\begin{array}{l}\text { 1. Cisplatin/ } \\
\text { pemetrexed } \\
04 / 14 \text { (x1)-Stop } \\
\text { for toxicity }\end{array}$ & $\begin{array}{c}\text { Not } \\
\text { evaluated }\end{array}$ \\
\hline & & & & & & & & & & $\begin{array}{l}\text { 2. Crizotinib } \\
\text { from 05/14 to } \\
07 / 15 \text {-Liver } \\
\text { metastases }\end{array}$ & $\begin{array}{l}\text { Partial } \\
\text { response }\end{array}$ \\
\hline & & & & & & & & & & $\begin{array}{l}\text { 3. Ceritinib from } \\
08 / 15 \text { to } 09 / 15\end{array}$ & $\begin{array}{l}\text { Progression } \\
\text { of disease }\end{array}$ \\
\hline & & & & & & & & & & $\begin{array}{l}\text { 4. Nivolumab } \\
10 / 15\end{array}$ & $\begin{array}{l}\text { Progression } \\
\text { of disease }\end{array}$ \\
\hline 3 & $\mathrm{~F} / 57$ & $04 / 14$ & $06 / 16$ & Never & T4N1M0 & IIIa & ADK/Lepidic & 50 & Split & $\begin{array}{l}\text { 1. Surgery } \\
+ \text { adjuvant } \\
\text { cisplatin/ } \\
\text { pemetrexed }\end{array}$ & $\begin{array}{l}\text { Complete } \\
\text { response }\end{array}$ \\
\hline \multirow[t]{2}{*}{4} & \multirow[t]{2}{*}{$\mathrm{M} / 56$} & \multirow[t]{2}{*}{$12 / 14$} & \multirow[t]{2}{*}{$01 / 17$} & \multirow[t]{2}{*}{$\begin{array}{l}\text { Current } \\
\text { (60) }\end{array}$} & \multirow[t]{2}{*}{$\mathrm{T} 4 \mathrm{Nx}$} & \multirow[t]{2}{*}{ IIIa } & \multirow[t]{2}{*}{ ADK/Solid } & \multirow[t]{2}{*}{60} & \multirow[t]{2}{*}{ IGS } & $\begin{array}{l}\text { 1. Surgery } \\
\text { + adjuvant } \\
\text { cisplatin/ } \\
\text { pemetrexed }\end{array}$ & $\begin{array}{l}\text { Partial } \\
\text { response }\end{array}$ \\
\hline & & & & & & & & & & $\begin{array}{l}\text { 2. Pemetrexed } \\
\text { maintenance } \\
\text { from } \\
07 / 15 \text {-ongoing }\end{array}$ & $\begin{array}{l}\text { Stable } \\
\text { disease }\end{array}$ \\
\hline 5 & $\mathrm{~F} / 90$ & $01 / 15$ & NA & NA & NA & NA & ADK/Solid & 80 & IGS+split & $\begin{array}{l}\text { Best supportive } \\
\text { care }\end{array}$ & / \\
\hline \multirow[t]{5}{*}{6} & \multirow[t]{5}{*}{$\mathrm{M} / 49$} & \multirow[t]{5}{*}{$02 / 15$} & \multirow[t]{5}{*}{$01 / 17$} & \multirow[t]{5}{*}{$\begin{array}{l}\text { Former } \\
(25)\end{array}$} & \multirow[t]{5}{*}{ T4N3M1 } & \multirow[t]{5}{*}{ IV } & \multirow[t]{5}{*}{ ADK/Solid } & \multirow[t]{5}{*}{50} & \multirow[t]{5}{*}{ IGS + split } & $\begin{array}{l}\text { 1. Cisplatin/ } \\
\text { pemetrexed/ } \\
\text { bevacizumab } \\
\text { from } 12 / 12 \text { to } \\
01 / 13(\mathrm{x} 2)\end{array}$ & $\begin{array}{c}\text { Progression } \\
\text { of disease }\end{array}$ \\
\hline & & & & & & & & & & $\begin{array}{l}\text { 2. Docetaxel } \\
\text { from } 02 / 13 \text { to } \\
05 / 13 \text { (x6), then } \\
\text { therapeutic break }\end{array}$ & $\begin{array}{l}\text { Stable } \\
\text { disease }\end{array}$ \\
\hline & & & & & & & & & & $\begin{array}{l}\text { 3. Paclitaxel } \\
\text { from } 02 / 14 \text { to } \\
05 / 14(\mathrm{x} 3)\end{array}$ & $\begin{array}{c}\text { Partial } \\
\text { response }\end{array}$ \\
\hline & & & & & & & & & & $\begin{array}{l}\text { 4. Erlotinib from } \\
08 / 14 \text { to } 10 / 14\end{array}$ & $\begin{array}{c}\text { Progression } \\
\text { of disease }\end{array}$ \\
\hline & & & & & & & & & & $\begin{array}{l}\text { 5. Gemcitabine } \\
\text { from } 10 / 14 \text { to } \\
12 / 14(x 3)\end{array}$ & $\begin{array}{l}\text { Progression } \\
\text { of disease }\end{array}$ \\
\hline
\end{tabular}

(Continued) 


\begin{tabular}{|c|c|c|c|c|c|c|c|c|c|c|c|}
\hline No & $\begin{array}{l}\text { Sex/ } \\
\text { Age }\end{array}$ & $\begin{array}{c}\text { ROS1 } \\
\text { diagnosis } \\
\mathbf{m m} / \mathbf{y y}\end{array}$ & $\begin{array}{l}\text { Last news } \\
\text { or death } \\
(+) \mathbf{m m} / \mathbf{y y}\end{array}$ & $\begin{array}{l}\text { Smoker } \\
\text { (pack- } \\
\text { year) }\end{array}$ & TNM & Stage & $\begin{array}{l}\text { Histological } \\
\text { subtype/ } \\
\text { Predominant } \\
\text { pattern }\end{array}$ & $\begin{array}{l}\text { FISH- } \\
\text { positive } \\
\text { rate }(\%)\end{array}$ & $\begin{array}{c}\text { FISH } \\
\text { pattern }\end{array}$ & $\begin{array}{c}\text { Lines of } \\
\text { treatment } \\
\text { Date } \mathrm{mm} / \mathrm{yy} \text { (nb } \\
\text { of cycles)-Cause } \\
\text { of therapeutic } \\
\text { escape }\end{array}$ & $\begin{array}{c}\text { Best } \\
\text { response }\end{array}$ \\
\hline & & & & & & & & & & $\begin{array}{l}\text { 6. Docetaxel } \\
\text { from } 01 / 15 \text { to } \\
02 / 15(x 3)\end{array}$ & $\begin{array}{c}\text { Progression } \\
\text { of disease }\end{array}$ \\
\hline & & & & & & & & & & $\begin{array}{l}\text { 7. Crizotinib } \\
\text { from } 03 / 15 \text { to } \\
09 / 16-\text {-Brain } \\
\text { metastases }\end{array}$ & $\begin{array}{c}\text { Partial } \\
\text { response }\end{array}$ \\
\hline & & & & & & & & & & $\begin{array}{c}\text { 8. Ceritinib } \\
\text { from } 09 / 16 \text { to } \\
01 / 17 \text {-Pericardial } \\
\text { metastases }\end{array}$ & $\begin{array}{c}\text { Partial } \\
\text { response }\end{array}$ \\
\hline \multirow[t]{4}{*}{7} & $\mathrm{M} / 30$ & $04 / 15$ & $02 / 17$ & Never & T2aN3M0 & IIIb & ADK/Lepidic & 70 & IGS + split & $\begin{array}{l}\text { 1. Carboplatin/ } \\
\text { paclitaxel from } \\
03 / 15 \text { to } 09 / 15\end{array}$ & $\begin{array}{c}\text { Partial } \\
\text { response }\end{array}$ \\
\hline & & & & & & & & & & $\begin{array}{l}\text { 2. Crizotinib } \\
\text { from } 10 / 15 \text { to } \\
03 / 16 \text {, then } \\
\text { therapeutic } \\
\text { break-brain } \\
\text { metastasis } 08 / 16\end{array}$ & $\begin{array}{c}\text { Stable } \\
\text { disease }\end{array}$ \\
\hline & & & & & & & & & & $\begin{array}{l}\text { 3. Carboplatin/ } \\
\text { paclitaxel from } \\
09 / 16 \text { to } 10 / 16\end{array}$ & $\begin{array}{c}\text { Progression } \\
\text { of disease }\end{array}$ \\
\hline & & & & & & & & & & $\begin{array}{l}\text { 4. Lorlatinib } \\
\text { 01/17-Stop } \\
\text { for toxicity } \\
\text { (intersitial } \\
\text { pneumopathy) }\end{array}$ & $\begin{array}{c}\text { Not } \\
\text { evaluated }\end{array}$ \\
\hline 8 & $\mathrm{M} / 52$ & $08 / 15$ & $07 / 15(+)$ & Never & T4NxM1b & IV & $\begin{array}{l}\text { Large cell } \\
\text { carcinoma }\end{array}$ & 90 & IGS+split & $\begin{array}{l}\text { 1. Carboplatin/ } \\
\text { paclitaxel (x1) }\end{array}$ & $\begin{array}{c}\text { Progression } \\
\text { of disease }\end{array}$ \\
\hline \multirow[t]{3}{*}{9} & $\mathrm{~F} / 59$ & $09 / 15$ & $07 / 16(+)$ & $\begin{array}{l}\text { Current } \\
(80)\end{array}$ & T3N3M1b & IV & ADK/Solid & 90 & Split & $\begin{array}{l}\text { 1. Surgery } \\
\text { + adjuvant } \\
\text { carboplatin/ } \\
\text { pemetrexed }\end{array}$ & $\begin{array}{c}\text { Partial } \\
\text { response }\end{array}$ \\
\hline & & & & & & & & & & $\begin{array}{c}\text { 2. Pemetrexed } \\
\text { maintenance } \\
\text { from } / 01 / 16 \text { to } \\
03 / 16\end{array}$ & $\begin{array}{c}\text { Stable } \\
\text { disease }\end{array}$ \\
\hline & & & & & & & & & & $\begin{array}{c}\text { 3. Crizotinib } \\
\text { from } 05 / 16 \text { to } \\
07 / 16^{*}\end{array}$ & $\begin{array}{c}\text { Progression } \\
\text { of disease }\end{array}$ \\
\hline \multirow[t]{2}{*}{10} & $\mathrm{M} / 77$ & $02 / 16$ & $01 / 17$ & $\begin{array}{c}\text { Former } \\
(5)\end{array}$ & $\mathrm{T} 2 \mathrm{~N} 2 \mathrm{M} 0$ & IIIa & $\begin{array}{c}\text { ADK/ } \\
\text { Papillary }\end{array}$ & 90 & Split & $\begin{array}{l}\text { 1. Surgery } \\
+ \text { adjuvant } \\
\text { carboplatin/ } \\
\text { vinorelbine }\end{array}$ & $\begin{array}{c}\text { Progression } \\
\text { of disease }\end{array}$ \\
\hline & & & & & & & & & & $\begin{array}{l}\text { 2. Crizotinib } \\
\text { from } \\
\text { 11/16-ongoing }\end{array}$ & $\begin{array}{l}\text { Complete } \\
\text { response }\end{array}$ \\
\hline
\end{tabular}

(Continued) 


\begin{tabular}{|c|c|c|c|c|c|c|c|c|c|c|c|}
\hline No & $\begin{array}{l}\text { Sex/ } \\
\text { Age }\end{array}$ & $\begin{array}{c}\text { ROS1 } \\
\text { diagnosis } \\
\text { mm/yy }\end{array}$ & $\begin{array}{l}\text { Last news } \\
\text { or death } \\
(+) \mathbf{m m} / \mathbf{y y}\end{array}$ & $\begin{array}{c}\text { Smoker } \\
\text { (pack- } \\
\text { year) }\end{array}$ & TNM & Stage & $\begin{array}{l}\text { Histological } \\
\text { subtype/ } \\
\text { Predominant } \\
\text { pattern }\end{array}$ & $\begin{array}{c}\text { FISH- } \\
\text { positive } \\
\text { rate }(\%)\end{array}$ & $\begin{array}{c}\text { FISH } \\
\text { pattern }\end{array}$ & $\begin{array}{c}\text { Lines of } \\
\text { treatment } \\
\text { Date } \mathrm{mm} / \mathrm{yy} \text { (nb } \\
\text { of cycles)-Cause } \\
\text { of therapeutic } \\
\text { escape }\end{array}$ & $\begin{array}{c}\text { Best } \\
\text { response }\end{array}$ \\
\hline 11 & $\mathrm{M} / 67$ & $02 / 16$ & $03 / 16$ & $\begin{array}{l}\text { Current } \\
(50)\end{array}$ & T2N0M0 & $\mathrm{Ib}$ & ADK/Acinar & 90 & Split & 1. Surgery & $\begin{array}{l}\text { Complete } \\
\text { response }\end{array}$ \\
\hline 12 & $\mathrm{M} / 67$ & $05 / 16$ & $01 / 17$ & $\begin{array}{l}\text { Former } \\
\text { (20) }\end{array}$ & T1bN3M1a & IV & ADK/Acinar & 90 & Split & $\begin{array}{l}\text { 1. Carboplatin/ } \\
\text { pemetrexed/ } \\
\text { bevacizumab } \\
\text { from } 02 / 16 \text { to } \\
05 / 16(\mathrm{x} 4)\end{array}$ & $\begin{array}{l}\text { Stable } \\
\text { disease }\end{array}$ \\
\hline 13 & $\mathrm{M} / 71$ & $05 / 16$ & $06 / 16$ & Never & T1aN0 & Ia & ADK/Acinar & 70 & IGS & 1. Surgery & $\begin{array}{l}\text { Complete } \\
\text { response }\end{array}$ \\
\hline 14 & $\mathrm{~F} / 58$ & $06 / 16$ & $02 / 17$ & Never & $\mathrm{T} 2 \mathrm{aN} 3 \mathrm{M} 1 \mathrm{~b}$ & IV & $\begin{array}{c}\text { ADK/ } \\
\text { Cytology }\end{array}$ & 80 & Split & $\begin{array}{l}\text { 1. Crizotinib } \\
\text { from } \\
\text { 08/16-ongoing }\end{array}$ & $\begin{array}{c}\text { Partial } \\
\text { response }\end{array}$ \\
\hline \multirow[t]{3}{*}{15} & $\mathrm{~F} / 54$ & $06 / 16$ & $02 / 17$ & Never & T4N0M1 & IV & ADK/Lepidic & 70 & IGS & $\begin{array}{l}\text { 1. Cisplatin/ } \\
\text { pemetrexed }\end{array}$ & $\begin{array}{c}\text { Progression } \\
\text { of disease }\end{array}$ \\
\hline & & & & & & & & & & 2. Erlotinib & $\begin{array}{c}\text { Partial } \\
\text { response }\end{array}$ \\
\hline & & & & & & & & & & 3. Crizotinib & $\begin{array}{l}\text { Complete } \\
\text { response }\end{array}$ \\
\hline
\end{tabular}

M: male; F: female; Split: split signals; IGS: isolated 3' green signal; NA: not available.

* Brain metastasis at the time of diagnosis.

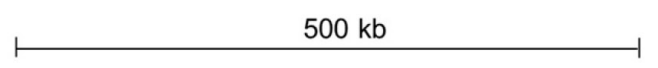

A

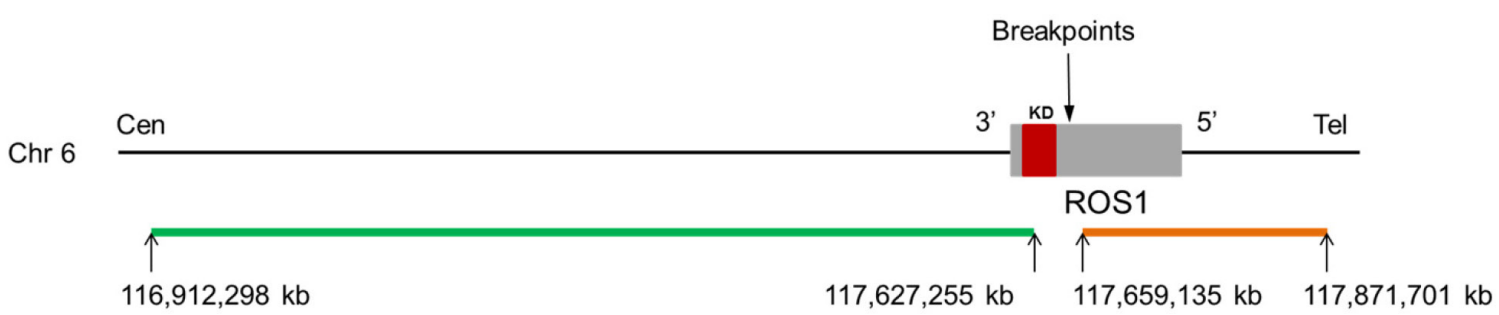

B

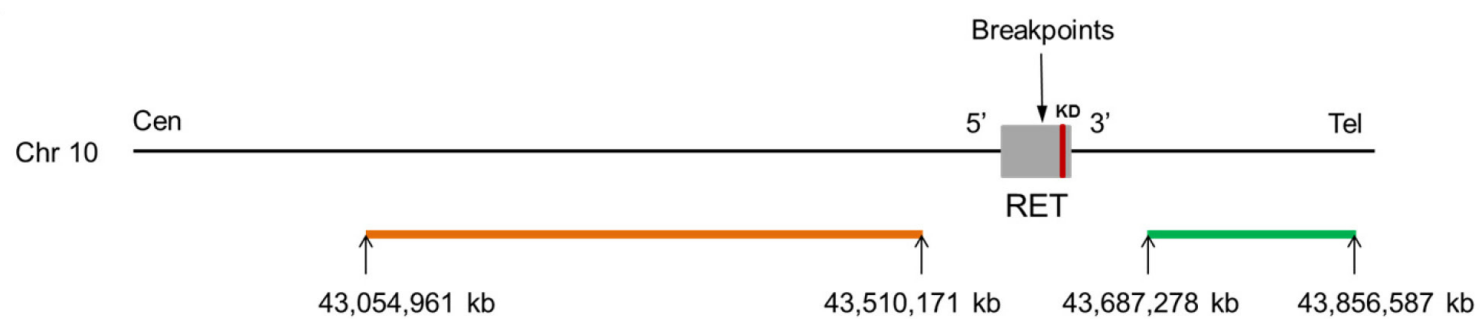

Figure 1: Map for ROS1 (A) and RET (B) dual color break-apart probes (ZytoLight ${ }^{\circledR}$ SPEC ROS1 and RET, ZytoVision). For both genes, the orange and green fluorochrome direct labeled probes hybridize proximal (5' end) and distal ( $3^{\prime}$ end) to the genes, respectively. The known breakpoints in ROS1 are located in introns 31, 33 and 34 and are proximal to the kinase domain (exons 36 to 41 ). For RET, the known breakpoints are located in introns 10 and 11 and are proximal to the kinase domain (exons 12 to 19). The precise location of the genes on the chromosome, the size $(\mathrm{kb})$ and orientation of the genes are indicated according to the Human assembly GRCh37/hg19. kb: kilobase pair; Cen: centromere; Tel: telomere; Chr: chromosome; KD: kinase domain. 
to $1 \%$ ROS1-positive cases i.e. similar levels than those reported by Warth et al. $(0.6 \%, 9 / 1478)$ and Jurmeister et al. $(0,8 \%, 4 / 473)[18,19]$. The notion that oncogenic fusions mainly affect young, female and non-smoker
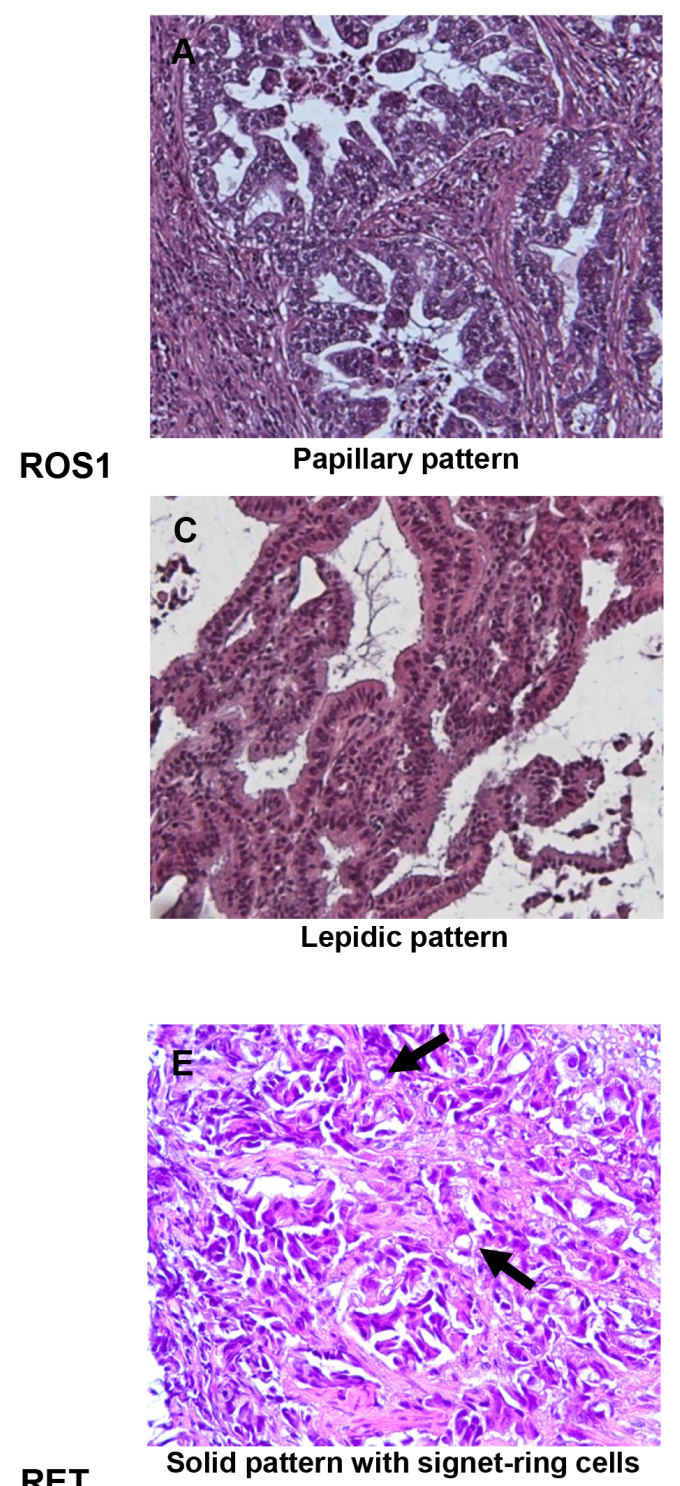

RET

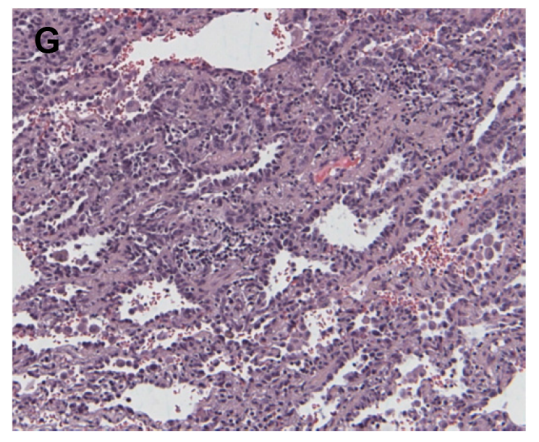

Lepidic pattern patients originated from the knowledge gained from studying ALK. However, recent meta-analyses dealing with ROS1 and RET depicted a more complex landscape $[15,16]$. In the Caucasian cohorts reviewed in the meta-

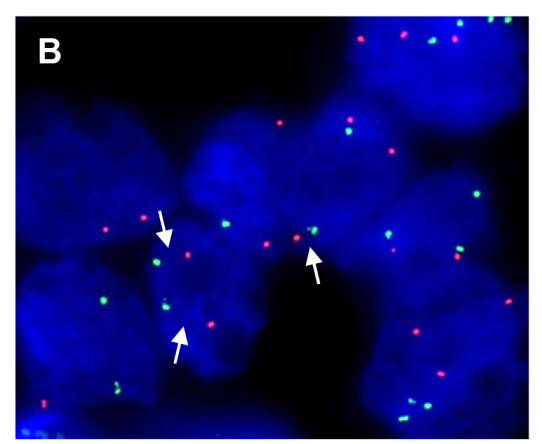

Break-apart pattern

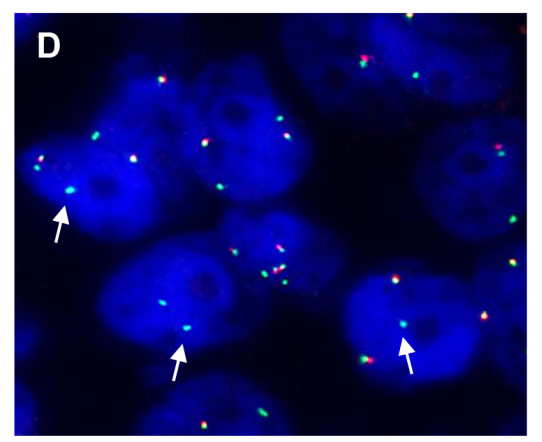

Isolated 3' green signals

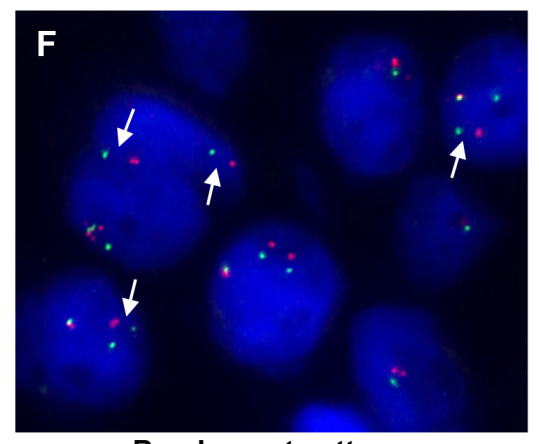

Break-apart pattern

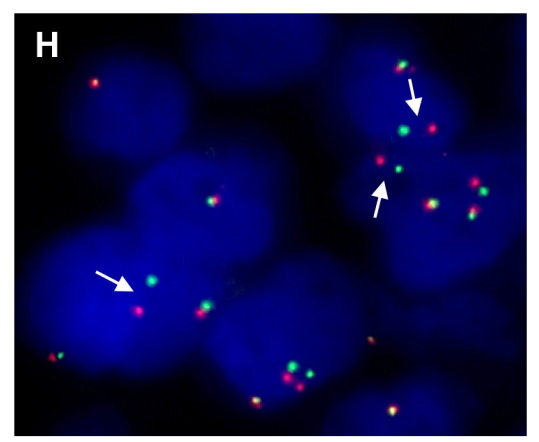

Break-apart pattern

Figure 2: Images of ROS1- or RET-rearranged lung adenocarcinoma. H\&E staining (A, C, E, G) and corresponding FISH profiles $(\mathbf{B}, \mathbf{D}, \mathbf{F}, \mathbf{H})$ are shown. Thin white arrows indicate split signals or isolated 3 ' green signals. Thick black arrows indicate signet-ring cells. H\&E: hematoxylin and eosin (200x); FISH: fluorescence in situ hybridization. 
analyses, female gender but not younger age was found to be associated with $R O S 1$ rearrangement $[18,19]$. In our study, the ROS1-rearranged patients were younger than the negative patients and ROS1 rearrangement was not found to be associated with the female gender. Interestingly, our study is the first to report the association of RET rearrangement with the female gender in the Caucasian population. On that topic, available data were inconclusive since Michels et al. identified more men and Sarfaty et al. more women among the RET-positive patients in European and Israeli cohorts, respectively [20, 21]. However, as the description of the entire cohort was lacking in both studies, conclusions regarding the association between RET rearrangement and gender could not be drawn. Concerning the history of smoking, ROS1 and RET fusions were found to be associated with no or light smoking. Nevertheless, it should be noted that the absolute number of smokers slightly exceeded that of non-smokers. Likewise, Michels et al. also reported smokers among the RET-positive patients in their European cohort [20]. Thus, it would be wise not to exclude smokers from the screening as some diagnostic algorithms suggest [22]. In addition, the stage of the disease at the time of diagnosis of RET fusion still remains to be established. Lee et al. reported that $R E T$ rearrangement mainly affects Asian patients with lowstage disease [17], whereas Michels et al. found more advanced stage disease among the Caucasian patients [20]. Similarly, our findings show a trend for high stage disease at the time of diagnosis. Finally, as reported in Asian studies, ROS1 and RET fusion genes were found in large cell and not otherwise specified carcinoma highlighting that the screening should not be restricted to adenocarcinoma [23, 24].

ROS1 and RET rearrangements have been recently discovered in NSCLC, and the reliability of immunohistochemistry (IHC) in identifying protein overexpression still need to be refined [25, 26]. Two ROS1-rearranged samples were negative for ROS1 expression by IHC. The first patient underwent a curative surgery and the second one achieved a complete response with crizotinib, further confirming the aberration of ROS1. IHC staining was also negative for a ROS1-amplified sample. Of note, the correlation between overexpression and amplification of ROS1 has been inconsistent $[27,28]$. The knowledge gained from studying ALK [29] also questions the consequences of increased copy numbers of ROS1 or RET. ROS1 CNG was found to be associated with shorter disease-free and overall survival by Jin et al. but not by Clavé et al. $[27,30]$. Here, CNG was more frequent for RET than for ROS1 and high levels of CNG (7 to 10 copies) were mainly restricted to $R E T$. The level of RET CNG was in accordance with the data from Yang et al. [31], but noticeably exceeded $10.9 \%$ as reported by Platt et al. [26]. In addition, we revealed a higher frequency of isolated 5' signals in RET compared to ALK or ROS1 FISH profiles. Oncogenic fusions of tyrosine kinases arise from chromosomal breaks, accompanied with or without the loss of adjacent DNA sequences [32, 33]. As most DNA breaks occur proximal to the exons encoding the kinase domain [34], isolated 5' signals are thought to denote the lack of the kinase domain and are considered negative. One must be aware that FISH probes often hybridize to regions surrounding the genes. Thus, the lack of 3' signals does not formally rule out the presence of the kinase domain. Recently, Li et al. reported a deletion right next to the kinase domain of $A L K$, which reduced the target region of the probe [35]. The remaining signal could not be detected by FISH, although the kinase domain was present. In addition, currently accumulating data suggest an unexpected complexity in the gene fusion landscape, including alternative breakpoints [36], breakpoints distal to the kinase domain $[34,37]$ or complex chromosomal rearrangements [32, 38-40]. Thus, caution should be exercised when drawing conclusion from atypical FISH profiles. Whether this observation is clinically relevant is currently unknown. However, if other groups confirm the unexpected frequency, the question whether these patients are eligible to TKIs will arise.

Nearly half of the ROS1-rearranged patients were successfully treated with ROS1 TKIs, except one patient who had brain metastases and progressed under crizotinib. This progression could be related to the poor penetration of the blood-brain barrier by crizotinib [41]. In case of relapse, the patients were usually given second- or third-generation TKIs, demonstrating that the ROS1-rearranged patients have entered fully into the era of targeted therapies. By contrast, few RETpositive patients received RET TKIs, often in third or subsequent line therapy, and the results have fallen short of expectations. First clinical trials evaluating RET TKIs have shown heterogeneous results with overall response rates ranging from 16 to $54 \%$ [42-45]. Of note, these results have been obtained with multi-kinase TKIs that are unlikely to ensure optimal RET inhibition. Fortunately, TKIs with more potent anti-RET activity are in advanced stages of clinical development [46, 47]. Faced with that concern, clinicians frequently prescribed pemetrexed-containing chemotherapy, in agreement with the valuable results that have been reported in fusion gene-driven NSCLC [48]. In addition, although studies have suggested little or no benefit of immune checkpoint inhibitors in oncogene-driven tumors [49], some patients were given nivolumab. A reduced total mutation burden has been proposed as an explanation for the low response rates [50], but confirmatory studies are warranted.

Finally, our study on a large cohort shows that $R E T$ rearrangement is as frequent as ROS1 rearrangement in Caucasian NSCLC patients. If available multi-kinase TKIs 


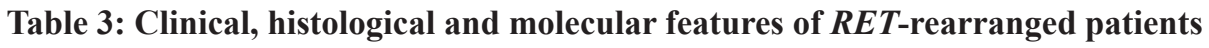

\begin{tabular}{|c|c|c|c|c|c|c|c|c|c|c|c|}
\hline No & $\begin{array}{l}\text { Sex/ } \\
\text { Age }\end{array}$ & $\begin{array}{c}\text { RET } \\
\text { diagnosis } \\
\mathbf{m m} / \mathbf{y y}\end{array}$ & $\begin{array}{c}\text { Last } \\
\text { news or } \\
\text { death } \\
(+) \mathrm{mm} / \\
\text { yy }\end{array}$ & $\begin{array}{c}\text { Smoker } \\
\text { (pack- } \\
\text { year) }\end{array}$ & TNM & Stage & $\begin{array}{l}\text { Histological } \\
\text { subtype/ } \\
\text { Predominant } \\
\text { pattern }\end{array}$ & $\begin{array}{c}\text { FISH- } \\
\text { positive } \\
\text { rate }(\%)\end{array}$ & $\begin{array}{c}\text { FISH } \\
\text { pattern }\end{array}$ & $\begin{array}{c}\text { Line of } \\
\text { treatment } \\
\text { Date mm/yy } \\
\text { (nb of cycles) } \\
\text { - Cause of } \\
\text { therapeutic } \\
\text { escape }\end{array}$ & Best response \\
\hline 1 & $\mathrm{M} / 75$ & $02 / 14$ & $01 / 16$ & $\begin{array}{c}\text { Former } \\
(10)\end{array}$ & T1aN0M0 & Ia & ADK/Acinar & 70 & Split & 1. Surgery & $\begin{array}{l}\text { Complete } \\
\text { response }\end{array}$ \\
\hline \multirow[t]{2}{*}{2} & $\mathrm{~F} / 54$ & $05 / 14$ & 09/14 (+) & Never & T4N3M1b & IV & ADK/Solid & 70 & Split & $\begin{array}{c}1 . \text { Brain } \\
\text { radiotherapy } \\
+ \text { cisplatine/ } \\
\text { pemetrexed } \\
\text { from } 05 / 14 \text { to } \\
07 / 14\end{array}$ & $\begin{array}{l}\text { Progression of } \\
\text { disease }\end{array}$ \\
\hline & & & & & & & & & & $\begin{array}{c}\text { 2. Vandetanib } \\
\text { from } 08 / 14 \text { to } \\
09 / 14\end{array}$ & $\begin{array}{l}\text { Progression of } \\
\text { disease }\end{array}$ \\
\hline \multirow[t]{3}{*}{3} & $\mathrm{M} / 60$ & $08 / 14$ & $01 / 16(+)$ & $\begin{array}{l}\text { Current } \\
\text { (35) }\end{array}$ & T4N3M1 & IV & ADK/Papillary & 50 & Split & $\begin{array}{l}\text { 1. Cisplatin/ } \\
\text { pemetrexed/ } \\
\text { bevacizumab } \\
\text { from } 08 / 14 \text { to } \\
10 / 14\end{array}$ & Partial response \\
\hline & & & & & & & & & & $\begin{array}{l}\text { 2. Nivolumab } \\
\text { from } 09 / 15 \text { to } \\
\qquad 12 / 15\end{array}$ & $\begin{array}{l}\text { Progression of } \\
\text { disease }\end{array}$ \\
\hline & & & & & & & & & & $\begin{array}{c}\text { 3. Paclitaxel } \\
\text { from } 12 / 15 \text { to } \\
01 / 16\end{array}$ & $\begin{array}{l}\text { Progression of } \\
\text { disease }\end{array}$ \\
\hline 4 & $\mathrm{~F} / 94$ & $09 / 14$ & $09 / 15$ & $\begin{array}{l}\text { Former } \\
(30)\end{array}$ & T1N0M0 & Ia & ADK/Solid & 50 & Split & $\begin{array}{l}\text { Best supportive } \\
\text { care }\end{array}$ & l \\
\hline \multirow[t]{4}{*}{5} & $\mathrm{~F} / 77$ & $10 / 14$ & $12 / 16$ & Never & TxNxM1 & IV & ADK/Acinar & 70 & IGS & $\begin{array}{l}\text { 1. Carboplatin/ } \\
\text { pemetrexed } \\
\text { from } 08 / 14 \text { to } \\
11 / 14(\mathrm{x} 4)\end{array}$ & Partial response \\
\hline & & & & & & & & & & $\begin{array}{c}\text { 2. Pemetrexed } \\
\text { maintenance } \\
\text { from } 12 / 14 \text { to } \\
04 / 15\end{array}$ & $\begin{array}{l}\text { Progression of } \\
\text { disease }\end{array}$ \\
\hline & & & & & & & & & & $\begin{array}{l}\text { 3. Sunitinib } \\
\text { from } 05 / 15 \text { to } \\
07 / 15\end{array}$ & $\begin{array}{l}\text { Progression of } \\
\text { disease }\end{array}$ \\
\hline & & & & & & & & & & $\begin{array}{l}\text { 4. Paclitaxel } \\
\text { from } 09 / 15 \text { to } \\
10 / 16 \text {, then } \\
\text { therapeutic } \\
\text { break }\end{array}$ & Stable disease \\
\hline 6 & $\mathrm{~F} / 87$ & $10 / 14$ & $01 / 15(+)$ & $\begin{array}{l}\text { Former } \\
(40)\end{array}$ & T4N2M1 & IV & $\begin{array}{c}\text { ADK/Solid } \\
\text { signet-ring cells }\end{array}$ & 50 & Split & $\begin{array}{l}\text { Best supportive } \\
\text { care }\end{array}$ & / \\
\hline 7 & $\mathrm{M} / 59$ & $10 / 14$ & $02 / 17$ & Never & T4N2M1 & IV & NOS & 70 & Split & $\begin{array}{l}\text { 1. Cisplatin/ } \\
\text { pemetrexed/ } \\
\text { bevacizumab } \\
\text { from } 8 / 14 \text { to } \\
10 / 14(x 4)\end{array}$ & Stable disease \\
\hline
\end{tabular}

(Continued) 


\begin{tabular}{|c|c|c|c|c|c|c|c|c|c|c|c|}
\hline No & $\begin{array}{l}\text { Sex/ } \\
\text { Age }\end{array}$ & $\begin{array}{c}\text { RET } \\
\text { diagnosis } \\
\mathbf{m m} / \mathbf{y y}\end{array}$ & $\begin{array}{c}\text { Last } \\
\text { news or } \\
\text { death } \\
(+) \mathrm{mm} / \\
\text { yy }\end{array}$ & $\begin{array}{c}\text { Smoker } \\
\text { (pack- } \\
\text { year) }\end{array}$ & TNM & Stage & $\begin{array}{c}\text { Histological } \\
\text { subtype/ } \\
\text { Predominant } \\
\text { pattern }\end{array}$ & $\begin{array}{c}\text { FISH- } \\
\text { positive } \\
\text { rate }(\%)\end{array}$ & $\begin{array}{c}\text { FISH } \\
\text { pattern }\end{array}$ & $\begin{array}{c}\text { Line of } \\
\text { treatment } \\
\text { Date } \mathrm{mm} / \mathrm{yy} \\
\text { (nb of cycles) } \\
\text { - Cause of } \\
\text { therapeutic } \\
\text { escape }\end{array}$ & Best response \\
\hline & & & & & & & & & & $\begin{array}{l}\text { 2. Pemetrexed } \\
\text { maintenance } \\
11 / 14 \text { - Stop for } \\
\text { toxicity, then } \\
\text { therapeutic } \\
\text { break }\end{array}$ & Stable disease \\
\hline & & & & & & & & & & $\begin{array}{c}\text { 3. Erlotinib } \\
\text { from } 08 / 15 \text { to } \\
02 / 16\end{array}$ & $\begin{array}{l}\text { Progression of } \\
\text { disease }\end{array}$ \\
\hline & & & & & & & & & & $\begin{array}{c}\text { 4. Nivolumab } \\
\text { from } 03 / 16 \text { to } \\
06 / 16\end{array}$ & $\begin{array}{l}\text { Progresion of } \\
\text { disease }\end{array}$ \\
\hline & & & & & & & & & & $\begin{array}{l}\text { 5. Vandetanib } \\
\text { from } 12 / 16 \text { - } \\
\text { ongoing }\end{array}$ & Stable disease \\
\hline 8 & $\mathrm{~F} / 75$ & $04 / 15$ & $03 / 16$ & Never & T2N0M0 & $\mathrm{Ib}$ & ADK/Cytology & 80 & Split & 1. Surgery & $\begin{array}{l}\text { Complete } \\
\text { response }\end{array}$ \\
\hline \multirow[t]{4}{*}{9} & $\mathrm{M} / 50$ & $05 / 15$ & $02 / 17(+)$ & $\begin{array}{l}\text { Current } \\
\text { (20) }\end{array}$ & T1N3M1 & IV & ADK/Solid & 80 & Split & $\begin{array}{l}\text { 1. Cisplatin/ } \\
\text { pemetrexed } \\
\text { from } 08 / 13 \text { to } \\
10 / 13(x 4)\end{array}$ & Partial response \\
\hline & & & & & & & & & & $\begin{array}{l}\text { 2. Pemetrexed } \\
\text { maintenance } \\
\text { from } 11 / 13 \text { to } \\
08 / 14, \text { then } \\
\text { therapeutic } \\
\text { break }\end{array}$ & Stable disease \\
\hline & & & & & & & & & & $\begin{array}{l}\text { 3. Pemetrexed } \\
\text { at bone } \\
\text { progression } \\
\text { from } 09 / 15 \text { to } \\
03 / 16 \text { - Stop for } \\
\text { toxicity }\end{array}$ & Stable disease \\
\hline & & & & & & & & & & $\begin{array}{c}\text { 4. Nivolumab } \\
\text { from } 10 / 16 \text { to } \\
01 / 17\end{array}$ & $\begin{array}{l}\text { Progression of } \\
\text { disease }\end{array}$ \\
\hline \multirow[t]{2}{*}{10} & \multirow[t]{2}{*}{$\mathrm{F} / 44$} & \multirow[t]{2}{*}{$06 / 15$} & \multirow[t]{2}{*}{$04 / 16(+)$} & \multirow[t]{2}{*}{ Never } & \multirow[t]{2}{*}{ T1N3M1b } & \multirow[t]{2}{*}{ IV } & \multirow[t]{2}{*}{ ADK/Solid } & \multirow[t]{2}{*}{50} & \multirow[t]{2}{*}{ Split } & $\begin{array}{c}\text { 1. Cisplatin/ } \\
\text { pemetrexed/ } \\
\text { bevacizumab } \\
\text { from } 06 / 15 \text { to } \\
09 / 15\end{array}$ & Partial response \\
\hline & & & & & & & & & & $\begin{array}{c}\text { 2. Paclitaxel } \\
\text { from } 10 / 15 \text { to } \\
03 / 16\end{array}$ & Partial response \\
\hline 11 & $\mathrm{~F} / 83$ & $06 / 15$ & $06 / 15(+)$ & Never & T3N3M1 & IV & ADK/Solid & 60 & Split & $\begin{array}{l}\text { 1. Gefitinib } \\
\text { from } 28 / 05 / 15 \\
\text { to death (3 } \\
\text { days) }\end{array}$ & $\begin{array}{l}\text { Progression of } \\
\text { disease }\end{array}$ \\
\hline 12 & $\mathrm{~F} / 88$ & $07 / 15$ & $07 / 15(+)$ & NA & M1a & IV & $\begin{array}{c}\text { ADK/ } \\
\text { Undetermined }\end{array}$ & 50 & Split & $\begin{array}{c}\text { 1. Gefitinib } \\
\text { from } 06 / 15 \text { to } \\
\text { death }\end{array}$ & $\begin{array}{l}\text { Progression of } \\
\text { disease }\end{array}$ \\
\hline
\end{tabular}

(Continued) 


\begin{tabular}{|c|c|c|c|c|c|c|c|c|c|c|c|}
\hline No & $\begin{array}{l}\text { Sex/ } \\
\text { Age }\end{array}$ & $\begin{array}{c}\text { RET } \\
\text { diagnosis } \\
\mathbf{m m} / \mathbf{y y}\end{array}$ & $\begin{array}{c}\text { Last } \\
\text { news or } \\
\text { death } \\
(+) \mathrm{mm} / \\
\text { yy }\end{array}$ & $\begin{array}{c}\text { Smoker } \\
\text { (pack- } \\
\text { year) }\end{array}$ & TNM & Stage & $\begin{array}{l}\text { Histological } \\
\text { subtype/ } \\
\text { Predominant } \\
\text { pattern }\end{array}$ & $\begin{array}{l}\text { FISH- } \\
\text { positive } \\
\text { rate }(\%)\end{array}$ & $\begin{array}{c}\text { FISH } \\
\text { pattern }\end{array}$ & $\begin{array}{c}\text { Line of } \\
\text { treatment } \\
\text { Date mm/yy } \\
\text { (nb of cycles) } \\
\text { - Cause of } \\
\text { therapeutic } \\
\text { escape }\end{array}$ & Best response \\
\hline 13 & $\mathrm{M} / 63$ & $11 / 15$ & $12 / 15$ & $\begin{array}{l}\text { Current } \\
(40)\end{array}$ & T2N0M0 & $\mathrm{Ib}$ & ADK/Solid & 50 & IGS & 1. Surgery & $\begin{array}{l}\text { Complete } \\
\text { response }\end{array}$ \\
\hline \multirow[t]{6}{*}{14} & \multirow[t]{6}{*}{$\mathrm{M} / 57$} & \multirow[t]{6}{*}{$12 / 15$} & \multirow[t]{6}{*}{$01 / 17(+)$} & \multirow[t]{6}{*}{$\begin{array}{l}\text { Current } \\
\text { (70) }\end{array}$} & \multirow[t]{6}{*}{ T4N3M1 } & \multirow[t]{6}{*}{ IV } & \multirow[t]{6}{*}{ ADK/Acinar } & \multirow[t]{6}{*}{60} & \multirow[t]{6}{*}{ IGS } & $\begin{array}{l}\text { 1. Cisplatin/ } \\
\text { docetaxel from } \\
06 / 14 \text { to } 08 / 14 \\
(\mathrm{x} 4)\end{array}$ & Partial response \\
\hline & & & & & & & & & & $\begin{array}{l}\text { 2. Pemetrexed } \\
\text { from } 09 / 14 \text { to } \\
06 / 15 \text { - Stop for } \\
\text { toxicity }\end{array}$ & Stable disease \\
\hline & & & & & & & & & & $\begin{array}{c}\text { 3. Nivolumab } \\
\text { from } 11 / 15 \text { to } \\
12 / 15\end{array}$ & $\begin{array}{l}\text { Progression of } \\
\text { disease }\end{array}$ \\
\hline & & & & & & & & & & $\begin{array}{l}\text { 4. Docetaxel } \\
\text { from } 01 / 16 \text { to } \\
05 / 16, \text { then } \\
\text { therapeutic } \\
\text { break - Brain } \\
\text { metastases }\end{array}$ & Partial response \\
\hline & & & & & & & & & & $\begin{array}{l}\text { 5. Erlotinib } \\
08 / 16\end{array}$ & $\begin{array}{l}\text { Progression of } \\
\text { disease }\end{array}$ \\
\hline & & & & & & & & & & $\begin{array}{l}\text { 6. Sunitinib } \\
11 / 16\end{array}$ & $\begin{array}{c}\text { Progression of } \\
\text { disease }\end{array}$ \\
\hline 15 & $\mathrm{M} / 68$ & $12 / 15$ & $12 / 15(+)$ & $\begin{array}{l}\text { Former } \\
(5)\end{array}$ & M1 & IV & $\begin{array}{c}\text { ADK/Solid } \\
\text { signet-ring cells }\end{array}$ & 60 & Split & $\begin{array}{l}\text { 1. Cisplatin/ } \\
\text { pemetrexed } \\
12 / 15(\mathrm{x} 1)\end{array}$ & $\begin{array}{l}\text { Progression of } \\
\text { disease }\end{array}$ \\
\hline \multirow[t]{3}{*}{16} & \multirow[t]{3}{*}{$\mathrm{F} / 80$} & \multirow[t]{3}{*}{$01 / 16$} & \multirow[t]{3}{*}{$03 / 17$} & \multirow[t]{3}{*}{ Never } & \multirow[t]{3}{*}{ T2N2M1 } & \multirow[t]{3}{*}{ IV } & \multirow[t]{3}{*}{$\begin{array}{c}\text { ADK/Solid } \\
\text { signet-ring cells }\end{array}$} & \multirow[t]{3}{*}{90} & \multirow[t]{3}{*}{ Split } & $\begin{array}{l}\text { 1. Carboplatin/ } \\
\text { paclitaxel from } \\
06 / 16 \text { to } 05 / 16 \\
\text { (x6) }\end{array}$ & Stable disease \\
\hline & & & & & & & & & & $\begin{array}{l}\text { 2. Paclitaxel } \\
\text { maintenance } \\
\text { (x9) - Stop for } \\
\text { toxicity } 11 / 16\end{array}$ & Stable disease \\
\hline & & & & & & & & & & $\begin{array}{l}\text { 3. Vandetanib } \\
\text { from } 12 / 16 \text { - } \\
\text { ongoing }\end{array}$ & Stable disease \\
\hline \multirow[t]{2}{*}{17} & \multirow[t]{2}{*}{$\mathrm{M} / 61$} & \multirow[t]{2}{*}{$04 / 16$} & \multirow[t]{2}{*}{$12 / 16$} & \multirow[t]{2}{*}{$\begin{array}{l}\text { Current } \\
(60)\end{array}$} & \multirow[t]{2}{*}{ T4N2M0 } & \multirow[t]{2}{*}{ IIIb } & \multirow[t]{2}{*}{ ADK/Acinar } & \multirow[t]{2}{*}{80} & \multirow[t]{2}{*}{ IGS } & $\begin{array}{l}\text { 1. Radiotherapy } \\
+ \text { carboplatin/ } \\
\text { paclitaxel from } \\
03 / 16 \text { to } 05 / 16\end{array}$ & $\begin{array}{l}\text { Progression of } \\
\text { disease }\end{array}$ \\
\hline & & & & & & & & & & $\begin{array}{l}\text { 2. Pemetrexed } \\
\text { from } 09 / 16 \text { to } \\
12 / 16(x 5)\end{array}$ & Stable disease \\
\hline 18 & $\mathrm{~F} / 43$ & $06 / 16$ & $07 / 16$ & $\begin{array}{l}\text { Former } \\
\text { (10) }\end{array}$ & T1aN0 & Ia & ADK/Lepidic & 90 & Split & 1. Surgery & $\begin{array}{l}\text { Complete } \\
\text { response }\end{array}$ \\
\hline
\end{tabular}

M: male; F: female; NOS: not otherwise specified; Split: split signals; IGS: isolated 3' green signal; NA: not available. 
Table 4: ROS1 and $R E T$ gene copy number in rearranged and non-rearranged samples

\begin{tabular}{lcccccc}
\hline & & $\mathbf{1}$ copy & 2 copies & 3 to 6 copies & $\mathbf{7}$ to 10 copies & $\begin{array}{c}>\mathbf{1 0} \text { copies or } \\
\text { clusters }\end{array}$ \\
\hline ROS1 & - & $49(7 \%)$ & $307(43.9 \%)$ & $341(49 \%)$ & 0 & $1(0.1 \%)$ \\
& + & $1(6.7 \%)$ & $9(60 \%)$ & $5(33.3 \%)$ & 0 & 0 \\
RET & - & $10(1.4 \%)$ & $220(31.6 \%)$ & $441(63.5 \%)$ & $24(3.5 \%)$ & 0 \\
& + & 0 & $6(33.3 \%)$ & $11(61.1 \%)$ & $1(5.5 \%)$ & 0 \\
\hline
\end{tabular}

have provided first clues for efficacy, TKIs designed to more potently target RET are hoped to achieve a better response rate. Given the reported frequencies, the number of patients potentially affected by a rearrangement of RET might exceed 20000 a year, worldwide. Therefore, we recommend the prompt implementation of routine
RET testing in non-squamous NSCLC patients, including those with a history of smoking. RNA sequencing, once validated and widely used in pathology laboratories, should considerably aid in such screening and improve the clinical management of RET-positive patients.

\section{IHC / H\&E}

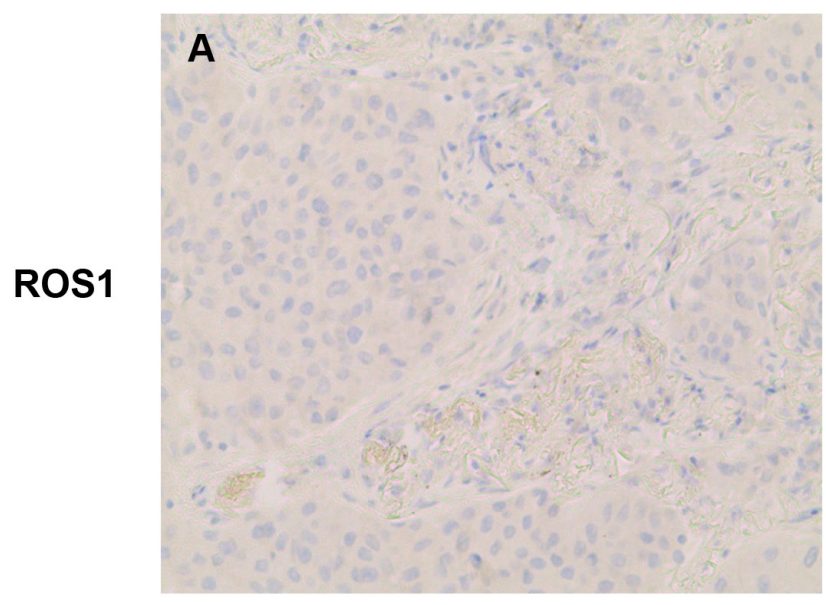

Negative IHC

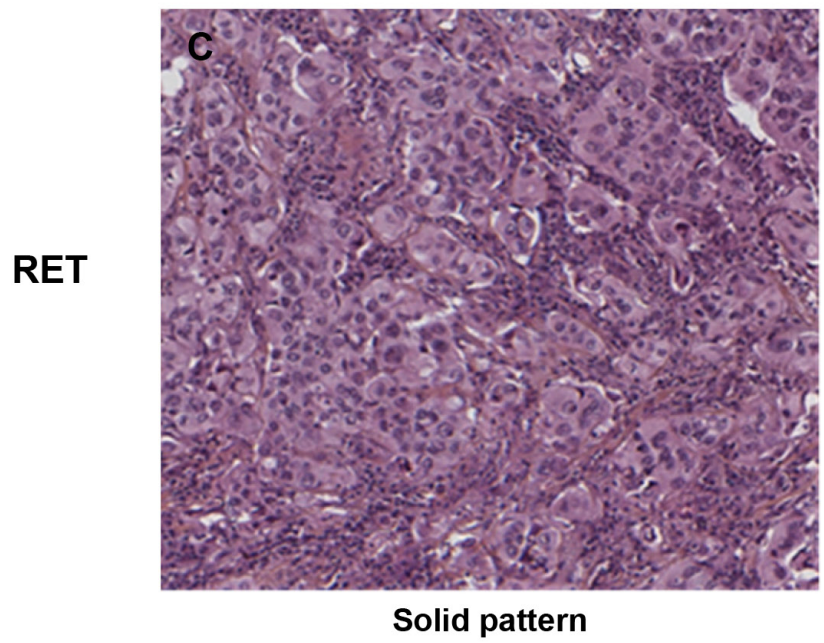

FISH

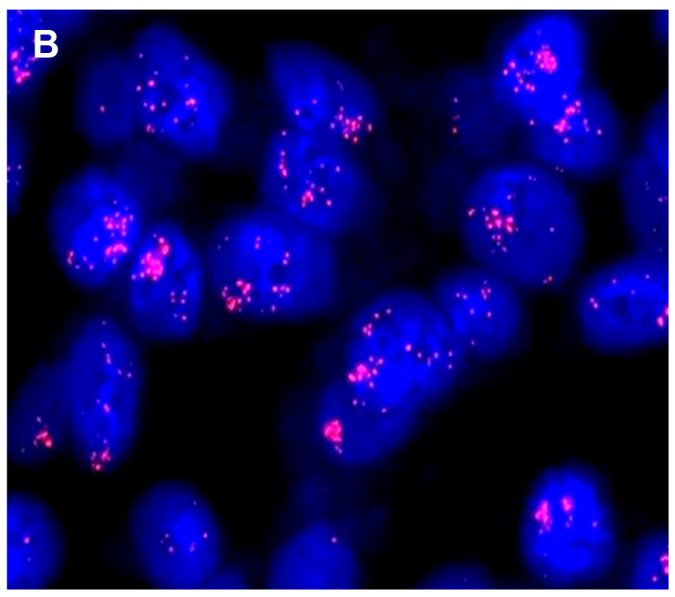

ROS1 amplification

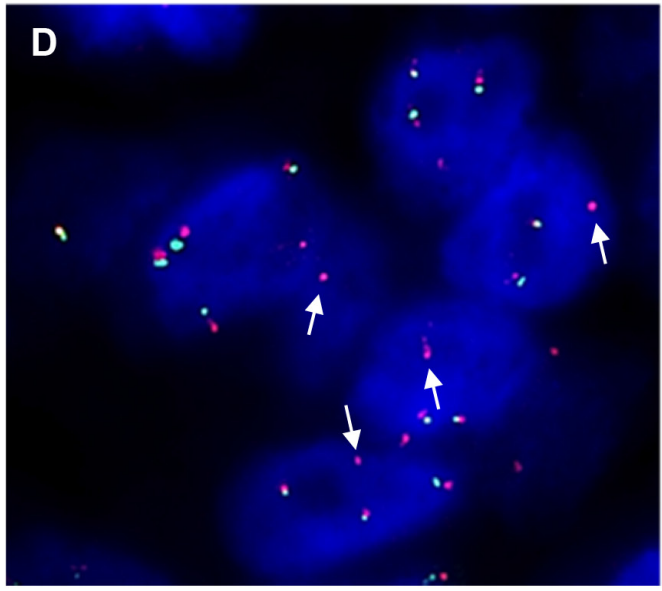

Isolated 5' orange signals

Figure 3: Images of samples with ROS1 amplification (A-B) and atypical isolated 5' signal pattern for RET (C-D). White arrows indicate isolated 5' orange signals. IHC: immunohistochemistry; H\&E: hematoxylin and eosin (200x); FISH: fluorescence in situ hybridization. 


\section{MATERIALS AND METHODS}

\section{Ethics statement}

The study was approved by the institutional ethics committee of the Rennes University Hospital.

\section{Patient and sample selection}

The pathology department at Rennes University Hospital is part of a network of hospital molecular genetics platforms that the French National Cancer Institute has been supporting since 2006. Formalin-fixed paraffin-embedded (FFPE) samples of NSCLC were sent at the time of diagnosis for molecular testing. They were collected from a population pool of three or four million inhabitants in western France. Then, the histological subtype was determined by experienced lung pathologists (FLG and DCC). Mutational screening was performed by pyrosequencing (PSQ 96MA, Qiagen, Courtaboeuf, France). Of 3,015 NSCLC samples sent to our pathology department between January 2014 and June 2016, 713 non-squamous NSCLC specimens with wild-type $E G F R /$ KRAS/HER2/BRAF/PIK3CA/ALK were prospectively assessed for ROS1 and RET rearrangements by using break-apart FISH assays. Treatment decisions and patient's care were at the medical oncologists' discretion. Best response to therapy was assessed using RECIST version 1.1. Data (clinical, pathological and molecular features) were collected centrally and analyzed by an independent statistician.

\section{Fluorescence in situ hybridization}

ROS1 and RET FISH assays were performed on $4-\mu \mathrm{m}$-thick sections of FFPE tissue blocks using ZytoLight SPEC ROS1 and RET dual color break-apart probes according to the manufacturer's instructions (ZytoVision, Bremerhaven, Germany). The design of the probes is depicted in Figure 1: the 5' orange and 3' green probes hybridized proximal and distal to the kinase domain, respectively. The slides were analyzed by 2 experienced cytogeneticists (FD and FC) by using a fluorescence microscope (Axioskop2, Axio Imager Z2, Zeiss, Göttingen, Germany) and Isis imaging software (Metasystems, Altlussheim, Germany). Per case, at least 100 non-overlapping tumor nuclei were examined. A sample was considered positive for rearrangement if at least $15 \%$ of the nuclei showed split signals or isolated 3' signals. Isolated 5' signals were thought to result from the deletion of exons encoding the kinase domain and were considered negative. Gene copy number per nucleus was recorded as follows: one copy, two copies, low copy number gain (3 to 6 copies), high copy number gain (7 to 10 copies) and amplification (> 10 copies or innumerable clusters).

\section{Immunohistochemistry}

ROS1 IHC was performed using the D4D6 clone (dilution 1:100; Cell Signaling Technology, Danvers, MA) with an ultrasensitive detection system (OptiView DAB IHC detection and amplification) on a BenchMark XT automated immunostainer (Ventana Medical Systems, Illkirch Graffenstaden, France).

\section{Mutation testing}

Mutational screening was performed by pyrosequencing (PSQ 96MA, Qiagen). Mutations in EGFR, KRAS, BRAF and PI3KCA were confirmed by allele-specific PCR (Light cycler ${ }^{\circledR}$ instrument $480 \mathrm{II}$, Roche molecular diagnostics, Pleasanton, CA). EGFR exon 19 deletions were confirmed by the analysis of amplified fragments on polyacrylamide gels, and EGFR/HER2 insertions were confirmed by direct sequencing (3130xl Genetics Analyzer, Life Technologies, Villebon-sur-Yvette, France).

\section{Statistical analysis}

The difference of the average age was assessed with a t test for ROS1 (normality of the distributions, homoscedasticity) and a Welsh test for RET (normality of the distributions, heteroscedasticity). Fisher's exact test for count data was used to investigate odds ratio. Data analysis was conducted using R statistical software.

\section{Abbreviations}

ALK: anaplastic lymphoma kinase; EGFR: epidermal growth factor receptor; FFPE: formalin-fixed paraffinembedded; FGFR: fibroblast growth factor receptor; FISH: fluorescence in situ hybridization; HER2: human epidermal growth factor receptor 2; KRAS: kirsten rat sarcoma viral oncogene homolog; NOS: not otherwise specified; NSCLC: non-small cell lung cancer; PI3KCA: phosphatidylinositol 3-kinase, catalytic subunit alpha; RET: rearranged during transfection; TKI: tyrosine kinase inhibitor.

\section{Author contributions}

FC and FD designed the study, performed the FISH analyses and wrote the manuscript; FLL and DCC performed the histological subtyping and the IHC analyses; MG, FM and SM contributed to the FISH analyses; HL and RL provided the clinical data; EB carried out the statistical analyses; MABR and NRL edited the manuscript.

\section{CONFLICTS OF INTEREST}

All authors have no conflicts of interest to disclose. 


\section{REFERENCES}

1. Torre LA, Bray F, Siegel RL, Ferlay J, Lortet-Tieulent J, Jemal A. Global cancer statistics, 2012. CA Cancer J Clin. 2015; 65: 87-108. doi: 10.3322/caac.21262.

2. Saito M, Shiraishi K, Kunitoh H, Takenoshita S, Yokota J, Kohno T. Gene aberrations for precision medicine against lung adenocarcinoma. Cancer Sci. 2016; 107: 713-20. doi: 10.1111/cas. 12941

3. Soda M, Choi YL, Enomoto M, Takada S, Yamashita Y, Ishikawa S, Fujiwara S, Watanabe H, Kurashina K, Hatanaka H, Bando M, Ohno S, Ishikawa Y, et al. Identification of the transforming EML4-ALK fusion gene in non-small-cell lung cancer. Nature. 2007; 448: 561-6. doi: 10.1038 /nature05945.

4. Shaw AT, Kim DW, Nakagawa K, Seto T, Crinó L, Ahn MJ, De Pas T, Besse B, Solomon BJ, Blackhall F, Wu YL, Thomas M, O'Byrne KJ, et al. Crizotinib versus chemotherapy in advanced ALK-positive lung cancer. $\mathrm{N}$ Engl J Med. 2013; 368: 2385-94. doi: 10.1056/ NEJMoa1214886.

5. Rikova K, Guo A, Zeng Q, Possemato A, Yu J, Haack H, Nardone J, Lee K, Reeves C, Li Y, Hu Y, Tan Z, Stokes M, et al. Global survey of phosphotyrosine signaling identifies oncogenic kinases in lung cancer. Cell. 2007; 131: 1190 203. doi: 10.1016/j.cell.2007.11.025.

6. Kohno T, Ichikawa H, Totoki Y, Yasuda K, Hiramoto M, Nammo T, Sakamoto H, Tsuta K, Furuta K, Shimada Y, Iwakawa R, Ogiwara H, Oike T, et al. KIF5B-RET fusions in lung adenocarcinoma. Nat Med. 2012; 18: 375-7. doi: 10.1038/nm.2644.

7. Uguen A, De Braekeleer M. ROS1 fusions in cancer: a review. Future Oncol. 2016; 12: 1911-28. doi: 10.2217/ fon-2016-0050.

8. Mulligan LM. RET revisited: expanding the oncogenic portfolio. Nat Rev Cancer. 2014; 14: 173-86. doi: 10.1038/ $\operatorname{nrc3680.}$

9. Birchmeier C, Sharma S, Wigler M. Expression and rearrangement of the ROS1 gene in human glioblastoma cells. Proc Natl Acad Sci U S A. 1987; 84: 9270-4.

10. Kohno T, Nakaoku T, Tsuta K, Tsuchihara K, Matsumoto $\mathrm{S}$, Yoh K, Goto K. Beyond ALK-RET, ROS1 and other oncogene fusions in lung cancer. Transl Lung Cancer Res. 2015; 4: 156-64. doi: 10.3978/j.issn.2218-6751.2014.11.11.

11. Shaw AT, Yeap BY, Mino-Kenudson M, Digumarthy SR, Costa DB, Heist RS, Solomon B, Stubbs H, Admane S, McDermott U, Settleman J, Kobayashi S, Mark EJ, et al. Clinical features and outcome of patients with non-smallcell lung cancer who harbor EML4-ALK. J Clin Oncol. 2009; 27: 4247-53. doi: 10.1200/JCO.2009.22.6993.

12. Hirsch FR, Suda K, Wiens J, Bunn PA Jr. New and emerging targeted treatments in advanced non-small-cell lung cancer. Lancet. 2016; 388: 1012-24. doi: 10.1016/ S0140-6736(16)31473-8.
13. Steuer CE, Behera M, Berry L, Kim S, Rossi M, Sica G, Owonikoko TK, Johnson BE, Kris MG, Bunn PA, Khuri FR, Garon EB, Ramalingam SS. Role of race in oncogenic driver prevalence and outcomes in lung adenocarcinoma: results from the lung cancer mutation consortium. Cancer. 2016; 122: 766-72. doi: 10.1002/cncr.29812.

14. Yamaguchi N, Vanderlaan PA, Folch E, Boucher DH, Canepa HM, Kent MS, Gangadharan SP, Majid A, Kocher ON, Goldstein MA, Huberman MS, Costa DB. Smoking status and self-reported race affect the frequency of clinically relevant oncogenic alterations in non-small-cell lung cancers at a United States-based academic medical practice. Lung Cancer. 2013; 82: 31-7. doi: 10.1016/j. lungcan.2013.07.013.

15. Zhu Q, Zhan P, Zhang X, Lv T, Song Y. Clinicopathologic characteristics of patients with ROS1 fusion gene in non-small cell lung cancer: a meta-analysis. Transl Lung Cancer Res. 2015; 4: 300-9. doi: 10.3978/j. issn.2218-6751.2015.05.01.

16. Lin C, Wang S, Xie W, Chang J, Gan Y. The RET fusion gene and its correlation with demographic and clinicopathological features of non-small cell lung cancer: a meta-analysis. Cancer Biol Ther. 2015; 16: 1019-28. doi: 10.1080/15384047.2015.1046649.

17. Lee SE, Lee B, Hong M, Song JY, Jung K, Lira ME, Mao M, Han J, Kim J, Choi YL. Comprehensive analysis of RET and ROS1 rearrangement in lung adenocarcinoma. Mod Pathol. 2015; 28: 468-79. doi: 10.1038/modpathol.2014.107.

18. Warth A, Muley T, Dienemann H, Goeppert B, Stenzinger A, Schnabel PA, Schirmacher P, Penzel R, Weichert W. ROS1 expression and translocations in non-small-cell lung cancer: clinicopathological analysis of 1478 cases. Histopathology. 2014; 65: 187-94. doi: 10.1111/his.12379.

19. Jurmeister P, Lenze D, Berg E, Mende S, Schäper F, Kellner U, Herbst H, Sers C, Budczies J, Dietel M, Hummel M, von Laffert M. Parallel screening for ALK, MET and ROS1 alterations in non-small cell lung cancer with implications for daily routine testing. Lung Cancer. 2015; 87: 122-9. doi: 10.1016/j.lungcan.2014.11.018.

20. Michels S, Scheel AH, Scheffler M, Schultheis AM, Gautschi O, Aebersold F, Diebold J, Pall G, Rothschild S, Bubendorf L, Hartmann W, Heukamp L, Schildhaus HU, et al. Clinicopathological characteristics of RET rearranged lung cancer in European patients. J Thorac Oncol. 2016; 11: 122-7. doi: 10.1016/j.jtho.2015.09.016.

21. Sarfaty M, Moore A, Neiman V, Dudnik E, Ilouze M, Gottfried M, Katznelson R, Nechushtan H, Sorotsky HG, Paz K, Katz A, Saute M, Wolner M, et al. RET fusion lung carcinoma: response to therapy and clinical features in a case series of 14 patients. Clin Lung Cancer. 2016. doi: 10.1016/j.cllc.2016.09.003. [Epub ahead of print].

22. Kobayashi M, Sonobe M, Takahashi T, Yoshizawa A, Kikuchi R, Date H. Detection of ALK fusion in lung cancer using fluorescence in situ hybridization. 
Asian Cardiovasc Thorac Ann. 2012; 20: 426-31. doi: 10.1177/0218492312440700.

23. Wang R, Pan Y, Li C, Zhang H, Garfield D, Li Y, Ye T, Hu H, Luo X, Li H, Zhang Y, Zhang J, Zhou X, et al. Analysis of major known driver mutations and prognosis in resected adenosquamous lung carcinomas. J Thorac Oncol. 2014; 9: 760-8. doi: 10.1097/JTO.0b013e3182a406d1.

24. Song Z, Yu X, Zhang Y. Clinicopathological characteristics and survival of ALK, ROS1 and RET rearrangements in non-adenocarcinoma non-small cell lung cancer patients. Cancer Biol Ther. 2016. doi: 10.1080/15384047.2016.1235660. [Epub ahead of print]

25. 2015 Lung External Quality Assessment of the European Society of Pathology. Available: http://lung.eqascheme.org/ info/public/alk/previous_participants.xhtml.

26. Platt A, Morten J, Ji Q, Elvin P, Womack C, Su X, Donald E, Gray N, Read J, Bigley G, Blockley L, Cresswell C, Dale A, et al. A retrospective analysis of RET translocation, gene copy number gain and expression in NSCLC patients treated with vandetanib in four randomized Phase III studies. BMC Cancer. 2015; 15: 171. doi: 10.1186/ s12885-015-1146-8.

27. Clavé S, Gimeno J, Muñoz-Mármol AM, Vidal J, Reguart N, Carcereny E, Pijuan L, Menéndez S, Taus Á, Mate JL, Serrano S, Albanell J, Espinet B, et al. ROS1 copy number alterations are frequent in non-small cell lung cancer. Oncotarget. 2016; 7: 8019-28. doi: 10.18632/ oncotarget.6921.

28. Lee HJ, Seol HS, Kim JY, Chun SM, Suh YA, Park YS, Kim S, Choi CM, Park SI, Kim DK, Kim YH, Jang SJ. ROS1 receptor tyrosine kinase, a druggable target, is frequently overexpressed in non-small cell lung carcinomas via genetic and epigenetic mechanisms. Ann Surg Oncol. 2013; 20: 200-8. doi: 10.1245/s10434-012-2553-6.

29. Peretti U, Ferrara R, Pilotto S, Kinspergher S, Caccese M, Santo A, Brunelli M, Caliò A, Carbognin L, Sperduti I, Garassino M, Chilosi M, Scarpa A, et al. ALK gene copy number gains in non-small-cell lung cancer: prognostic impact and clinico-pathological correlations. Respir Res. 2016; 17: 105. doi: 10.1186/s12931-016-0422-8.

30. Jin Y, Sun PL, Kim H, Park E, Shim HS, Jheon S, Kim K, Lee CT, Chung JH. ROS1 gene rearrangement and copy number gain in non-small cell lung cancer. Virchows Arch. 2015; 466: 45-52. doi: 10.1007/s00428-014-1679-2.

31. Yang HS, Horten B. Gain of copy number and amplification of the RET gene in lung cancer. Exp Mol Pathol. 2014; 97: 465-9. doi: 10.1016/j.yexmp.2014.10.002.

32. Seki Y, Mizukami T, Kohno T. Molecular process producing oncogene fusion in lung cancer cells by illegitimate repair of DNA double-strand breaks. Biomolecules. 2015; 5: 2464-76. doi: 10.3390/biom5042464.
33. Mizukami T, Shiraishi K, Shimada Y, Ogiwara H, Tsuta K, Ichikawa H, Sakamoto H, Kato M, Shibata T, Nakano T, Kohno T. Molecular mechanisms underlying oncogenic RET fusion in lung adenocarcinoma. J Thorac Oncol. 2014; 9: 622-30. doi: 10.1097/JTO.0000000000000135.

34. Shaw AT, Hsu PP, Awad MM, Engelman JA. Tyrosine kinase gene rearrangements in epithelial malignancies. Nat Rev Cancer. 2013; 13: 772-87. doi: 10.1038/nrc3612.

35. Li W, Zhang J, Guo L, Chuai S, Shan L, Ying J. Combinational analysis of FISH and immunohistochemistry reveals rare genomic events in ALK fusion patterns in NSCLC that responds to crizotinib treatment. J Thorac Oncol. 2017; 12: 94-101. doi: 10.1016/j.jtho.2016.08.145.

36. Penzel R, Schirmacher P, Warth A. A novel EML4ALK variant: exon 6 of EML4 fused to exon 19 of ALK. J Thorac Oncol. 2012; 7: 1198-9. doi: 10.1097/ JTO.0b013e3182598af3.

37. Kim SY, Ahn T, Bang H, Ham JS, Kim J, Kim ST, Jang J, Shim M, Kang SY, Park SH, Min BH, Lee H, Kang WK, et al. Acquired resistance to LY2874455 in FGFR2amplified gastric cancer through an emergence of novel FGFR2-ACSL5 fusion. Oncotarget. 2017; 8: 15014-22. doi: 10.18632/oncotarget.14788.

38. Jang JS, Wang X, Vedell PT, Wen J, Zhang J, Ellison DW, Evans JM, Johnson SH, Yang P, Sukov WR, Oliveira AM, Vasmatzis G, Sun Z, et al. Custom gene capture and next-generation sequencing to resolve discordant ALK status by FISH and IHC in lung adenocarcinoma. J Thorac Oncol. 2016; 11: 1891-900. doi: 10.1016/j. jtho.2016.06.001.

39. Mansfield AS, Murphy SJ, Harris FR, Robinson SI, Marks RS, Johnson SH, Smadbeck JB, Halling GC, Yi ES, Wigle D, Vasmatzis G, Jen J. Chromoplectic TPM3ALK rearrangement in a patient with inflammatory myofibroblastic tumor who responded to ceritinib after progression on crizotinib. Ann Oncol. 2016; 27: 2111-7. doi: 10.1093/annonc/mdw405.

40. Kodama T, Motoi N, Ninomiya H, Sakamoto H, Kitada K, Tsukaguchi T, Satoh Y, Nomura K, Nagano H, Ishii N, Terui Y, Hatake K, Ishikawa Y. A novel mechanism of EML4-ALK rearrangement mediated by chromothripsis in a patient-derived cell line. J Thorac Oncol. 2014; 9: 1638-46. doi: 10.1097/JTO.0000000000000311.

41. Costa DB, Kobayashi S, Pandya SS, Yeo WL, Shen Z, Tan W, Wilner KD. CSF concentration of the anaplastic lymphoma kinase inhibitor crizotinib. J Clin Oncol. 2011; 29: e443-5. doi: 10.1200/JCO.2010.34.1313.

42. Rosell R, Karachaliou N. RET inhibitors for patients with RET fusion-positive and RET wild-type non-small-cell lung cancer. Lancet Oncol. 2016; 17: 1623-5. doi: 10.1016/ S1470-2045(16)30557-5. 
43. Drilon A, Rekhtman N, Arcila M, Wang L, Ni A, Albano M, Van Voorthuysen M, Somwar R, Smith RS, Montecalvo J, Plodkowski A, Ginsberg MS, Riely GJ, et al. Cabozantinib in patients with advanced RET-rearranged non-small-cell lung cancer: an open-label, single-centre, phase 2, singlearm trial. Lancet Oncol. 2016; 17: 1653-60. doi: 10.1016/ S1470-2045(16)30562-9.

44. Lee SH, Lee JK, Ahn MJ, Kim DW, Sun JM, Keam B, Kim TM, Heo DS, Ahn JS, Choi YL, Min HS, Jeon YK, Park K. Vandetanib in pretreated patients with advanced non-small cell lung cancer-harboring RET rearrangement: a phase II clinical trial. Ann Oncol. 2017; 28: 292-7. doi: 10.1093/ annonc/mdw559.

45. Yoh K, Seto T, Satouchi M, Nishio M, Yamamoto N, Murakami H, Nogami N, Matsumoto S, Kohno T, Tsuta K, Tsuchihara K, Ishii G, Nomura S, et al. Vandetanib in patients with previously treated RET-rearranged advanced non-small-cell lung cancer (LURET): an open-label, multicentre phase 2 trial. Lancet Respir Med. 2017; 5: 42-50. doi: 10.1016/S2213-2600(16)30322-8.

46. Lin JJ, Kennedy E, Sequist LV, Brastianos PK, Goodwin KE, Stevens S, Wanat AC, Stober LL, Digumarthy SR, Engelman JA, Shaw AT, Gainor JF. Clinical activity of alectinib in advanced RET-rearranged non-small cell lung cancer. J Thorac Oncol. 2016; 11: 2027-32. doi: 10.1016/j. jtho.2016.08.126.
47. Velcheti V, Hida T, Reckamp KL, Yang JC, Nokihara H, Sachdev P, Feit K, Kubota T. Phase 2 study of lenvatinib (LN) in patients (Pts) with RET fusion-positive adenocarcinoma of the lung. Ann Oncol. 2016; 27: vi416-54.

48. Drilon A, Bergagnini I, Delasos L, Sabari J, Woo KM, Plodkowski A, Wang L, Hellmann MD, Joubert P, Sima CS, Smith R, Somwar R, Rekhtman N, et al. Clinical outcomes with pemetrexed-based systemic therapies in RET-rearranged lung cancers. Ann Oncol. 2016; 27: 128691. doi: 10.1093/annonc/mdw163.

49. Gainor JF, Shaw AT, Sequist LV, Fu X, Azzoli CG, Piotrowska Z, Huynh TG, Zhao L, Fulton L, Schultz KR, Howe E, Farago AF, Sullivan RJ, et al. EGFR mutations and ALK rearrangements are associated with Low response rates to PD-1 pathway blockade in non-small cell lung cancer: a retrospective analysis. Clin Cancer Res. 2016; 22 : 4585-93. doi: 10.1158/1078-0432.CCR-15-3101.

50. Saito M, Shimada Y, Shiraishi K, Sakamoto H, Tsuta K, Totsuka H, Chiku S, Ichikawa H, Kato M, Watanabe SI, Yoshida T, Yokota J, Kohno T. Development of lung adenocarcinomas with exclusive dependence on oncogene fusions. Cancer Res. 2015; 75: 2264-71. doi: 10.1158/00085472.CAN-14-3282. 